\title{
"JAWI" LANGUAGE AND ITS ROLE IN ESTABLISHMENT CIVILIZATION OF MALAYONESIA
}

\author{
Noriah Mohamed \\ Center for the Study of Humanities at Universiti Sains Malaysia \\ 11800 Penang Island, Malaysia \\ Email: noriahm@usm.my
}

\begin{abstract}
Language has an important role as an element of civilization. Similarly Jawi language. This paper seeks to prove that Jawi Language is a hybrid language born from the clash between Arabic and Malay in the archipelago or Southeast Asia. Using the sociolinguistic point of view this article also shows that Jawi Language has contributed significantly to the formation of civilizations in the Malay and Indonesian Malay world. Jawi language is apparently used not only as the language of instruction in daily interactions, but also as a language of science, language, culture, diplomatic language, and even the language of unity among Malay nations in the Malayonesia region.
\end{abstract}

Keywords: Jawi Language, Hybrid Language, Malayonesia Civilization

\section{Introduction}

When discussing Arabic and its role in the formation of Malayonesia civilization, we are inseparable from the role of language, which was called by past scientists in Malayonesia as Jawi language. One historical fact that we cannot deny is the Jawi language, as a derivative born of marriage between Arabic and Malay, is a language that plays an important role in the formation of Malayonesia civilization. The hybrid language not only serves as a unifying tool for tribes in diverse Malayonesia and even becomes a skillful vehicle for articulating scientific matters, in addition to playing a large role as a diplomatic and governmental language. In a more general phrase, the Islamic entity and Malayness' Malayism get a concrete form through Jawi language whose spirit contains substances and the nature of Arabic and Malay.

Studies of the role of Jawi language have been carried out by several researchers. One of them is Masyhur's writings, which found that the Jawi language was an important language of science in the Islamic intellectual tradition in the Malay world. Unfortunately, the Jawi language in the Malay world today has become a forgotten intellectual tradition of Islam (Masyhur, 2015: 230-231).

This article aims to discuss the role of Jawi language in the formation of Malay civilization. To apply this simple desire, the following points will be discussed: First, the clash of Malay languages and the birth of the Jawi language. Second, Jawi language, a distinctive language. Third, Jawi language as a consolidation of Malay. Fourth, Jawi language as a diplomatic and state language. Fifth, Jawi language is a language of science and communication.

\section{Clash of Languages in Malayonesia and Birth of the Jawi Language}

When two or more languages collide in physical space (or geographical space) and certain social spaces, the effect can be seen in at least two terms. The first impression is the emergence of a dominant linguistic system or new language that is influenced by population 
size and contact language status. The second effect is the emergence of a hybrid linguistic system or hybrid language. Cross language means two or more linguistic systems appear in the linguistic system. Thus linguistics sees the symptoms of cultural and civilization collisions followed simultaneously by language collisions, namely by perceiving their impact on the linguistic system of the language involved in the collision (Sarah Thomason, 2001).

In Malayonesia, such a situation is no stranger. Cultural clashes that are closely followed by language clashes (even conflicts) produce complex and otherwise very linguistic impressions. It is interesting to note that Ansaldo (2007) for example has challenged and cast the theory of a new language collision based solely on the information of the language resulting from the general collapse of Southeast Asia and Malayia in particular. One of the linguistic effects that is said to be complicated but interesting to see further is the formation of the Jawi language. A good problem to be asked about this language is whether the Jawi language, which is descended from marriage between Arabic and Malay, can be considered as a truly new language that has its own spirit and body that are separate from the mother who gave birth, namely language Malay?

Many writers, including Francois Valentyn, Thomas Bowrey, William Marsden, Wilkinson and even Za'ba themselves, and the majority of contemporary linguistic linguists in Malaysia, in particular, do not regard Jawi as a pure and pure new language (Za'ba 2013: 20) . In their general assumption, the Jawi language is only Malay. This variety is only used in Malay and Malay literary traditions, especially in the 14th century (based on the stone dates of Kuala Berang / Terengganu) until the early 20th century (before standardization of languages in Indonesia and in Malaysia). With a simpler statement, the Jawi language is said to be a variation of the Malay text used in religious works and other strong Arabic influences.

To debate the issue of the status of Jawi language, we first need to understand the nature of the clash of languages. The reason is to understand the consequences, we need to understand the cause. The pointer is very easy to understand, which is why it always leads to consequences and causes are always results.

Language clash is said to occur when there is more than one language in an area. This situation happened well (i) in areas that were previously uninhabited but were then inhabited by communities from various languages. This can be seen especially in newly opened cities, such as in Putrajaya. In addition, language clashes (ii) emerged in occupied areas, then were targeted by migrants from various backgrounds and cultures. Examples of these areas are Australia, the United States, Canada, New Zealand, South Africa and others. Languages in the region (i) and (ii) that interact, influence each other, and interact with each other. This situation produces a final impression, the emergence of a new linguistic system.

The results of the interaction, influence and disputes are victory and defeat: there is a winning language, immediately received remarks from the various languages as intermediary languages (eg Koine, Pijin and / or Creole). This language can eventually become a native language. Meanwhile, there are also missing languages, languages that are not accepted as intermediary languages. However, whether it wins or loses, the facts show that all the languages involved in the clash influence each other. Therefore, the actual results of the clash of languages are (i) the formation of new languages and (ii) the formation of cross language.

However, the symptoms of language disputes that allow highlighting stated results are not as easy as possible, but there are sociological and psychological reasons that must be considered carefully. First, because of sociology. The state and population ratio in language clashes determine the final outcome of the clash. With this situation, it means that the way a collision occurs in an area. There are two of the most common ways, namely: (i) voluntary 
migration (on economic, political and social impulses) and forcibly (workers and coolies brought from outside); and, (ii) colonization, namely the formation of new colonies in the upper class in certain colonized areas. In addition to clashes, the situation also refers to conflicting relations between communities, such as employers with workers, government classes with classes that are controlled and others. With a ratio too, that means, the population, for example, many opponents and so on.

Second, psychological reasons. Because there is a social imbalance as imagined in the first cause, the impact is also felt in the psychological space of the people involved in the collision. When too many languages are spoken in an area, this situation creates at least a relationship problem, that is, they do not or do not understand their own language. So what is the connection if we don't understand the language spoken by our neighbors or friends? To overcome this problem, the principle was created as suggested by Rudi Keller, who spoke like someone else spoke (Keller, 1996). However, Keller's principle is also rather problematic, what language should be used as a conversation model? The first reason is to provide a solution, which is to speak in a language that is more prestigious socially, economically and politically.

However, the clash was one thing, but the formation of a new language was another thing. The use of an intermediary language cannot be said as a new language. In linguistic terms, this language is called pijin, koine, and creole. The reason is that the role of this type of language is only one, namely to facilitate community relations with different backgrounds. Intermediate language can only be a new language when the language is spoken as a native language by the next generation. That is, the transition of generations is important. The first generation of migrants can only speak in fluent language. Pijin will only turn into a complete language at least after the second generation and / or the next generation to start using it as the first language.

\section{Historical Review of Language Clashes}

Language collisions in Melayonesia we are presented with a beautiful panorama of language collisions and the formation of new languages. This review is based on a summary of Adelaar \& Prentice (1996) with little observation. Generally, the symptoms of language disputes and new language formations can be observed periodically, by following models commonly used by historians. The following is a summary:

\section{Hindu-Buddhist People}

This period usually involves the majesty of the Srivijaya kingdom. At this time, we do not know exactly whether the clash between Kunlun (Malay) and Sanskrit language has given birth to a new language or hybrid language. If the style of carving inscriptions found in Sumatra is considered, the weapon that we can take is to relate it to cross-language, which is a mixture of Malay and Sanskrit through Malay. We also do not know whether hybrid languages are widely used in the Palembang River, Musi River or in all Malay States. Maybe this language was actually not spoken by civilians but only functioned as a written language, which was understood only by the king, the priests and the king's representatives on the outskirts of the city.

\section{Islamic Times and Business Times}

The Islamic era will not be touched in detail here because this time will be debated later. What needs to be stated about the Islamic Age here is that the current language clash produces interesting sociolinguistic symptoms. One of them is the acceptance of Malay as a 
broad language of relations. In the Islamic era, it was covered by an era referred to by Anthony Reid (1988) as the Trading Age. Today, language clashes are booming. Just check out the famous works, including Sulalatus Salatin which mentions the existence of multilingual tribal groups gathering in the port of Melaka. Symptoms of mixing languages, for example in the port of Malacca, gave birth to a language now known as the Malay market or hybrid language. Islam and the Age also emerged as a new language, spoken in Baba, especially in the Straits Settlements, namely Temasik, Malacca and Penang and Ceti Melayu, which were also available in Malacca.

\section{Age of Occupation and Post-Colonialism}

Panorama in the Jurisdiction Era is rather complicated. Involving not only brought colonies of colonies, but also brought other countries as forced labor, such as Britain in Malaya and the Netherlands in Indonesia. The Portuguese colonists only managed to bring the Portuguese colonies. They do not bring other countries, for example to Malacca, Macau or Malaku. Language clashes during Portuguese colonialism gave birth to a new language known as Papia Kristang. This language is still spoken by the Serani people in Malacca although it is no longer widely used. In addition, especially during the British colonial period, there was also the Baba Malay language. The existence of this language is due to the continuation of the previous generation since the Malacca era and the emergence of new communities brought by the British. The same applies to Ceti Malay. The post-colonial era shows the rise of English and English English Singapore which is different from English in the United Kingdom, United States, Australia or New Zealand - just look at the language used in the popular drama series Singapore, Phua Chu Kang.

\section{Contemporary Period and Future Possibilities}

Now and in the future, we can see the emergence of new crosses. There are two languages that are most likely to emerge, namely Bangla Malay Language. This is because many foreign workers from Bangladesh were brought to Malaysia. Malay Chinese eggs (Chinese Malay?) It may also appear if a ferocious expansion policy by the People's Republic of China gets a neat place in the region. Next we will discuss the clash of languages in the Islamic Age in more detail. This period must be discussed in a special section such as at that time that the Jawi language which had become a discussion emerged.

The Indonesian Malay Islamic theory, which was surpassed by al-Attas (1972), determined that the arrival of Islam into the region had changed the Malay nation as a whole. In addition to the transition of beliefs and beliefs in diversity, these changes can be seen clearly from a psychological point of view, namely the ability to perceive reality (reality) based on monotheistic binoculars, no longer based on stingray, spirit, genie or superstition. Oneness is the basis for the formation of new natural views and with a natural view that Malaysians build a civilization of religion and knowledge.

The change in akali and zahiri of Malaysians due to Islamization is also imagined if examined from a sociolinguistic and pure linguistic perspective. From the first point of view, namely sociolinguistics, it is the adoption of Malay language rather than a peripheral language to a language that is of a national and racial nature other than as a language of high scientific vehicles. From a pure linguistic point of view, the existence of a system of writings borrowed from Arabic script adapted to Malay language to be accepted as a common Malay literacy system. 
The most important thing to do with the description above is the insight that Islam has made Malay language a new language. It is said that the new language is because Malay language has risen high, that is, from a language that previously was not so empowered to support the truth and reveal the truth with a noble and orderly line of thought and right into a language which contains a blue lazuardi ketauhidan and scientific echo bitara.

The important phrase here is a new language. The brief description above defines a new language philosophically. The question is whether other meanings are contained in this phrase especially linguistic meaning? Fortunately we can impose new language phrases to be defined linguistically. We have mentioned the character system, which is the existence of Jawi characters based on Arabic characters. The meaning is that the new language refers to changes in character, which originates from the Palawa character with strong influences from Sanskrit languages and characters used previously for Jawi characters. In other words, a new language phrase is nothing but a change in character. Have another meaning?

Fortunately there are, which involve vocabulary. There are two things to remember about vocabulary. The first is the touching dimension of the meaning of the original Malay vocabulary. The second is to hover around the loan and absorb Arabic vocabulary into Malay.

First of all, all Islam has changed the meaning of many original Malay vocabulary. This change in meaning is more in the vocabulary that supports and shapes the structure of ancient Malay views. The most commonly used example is the word 'Noble Gods of the Kingdom'. This term is carved in the stone of Kuala Berang. The term 'Great Majesty' originally referred to the divine concept in an animist view. However, this term is still used by stone sculptors inscribed. That meaning has changed, namely by giving the color of Islam. Other terms borrowed from Sanskrit including heaven, hell, sin, merit and donations also change the meaning of a more Islamic understanding.

Islam has included Arabic vocabulary into Malay. In addition to everyday vocabulary, the most important Arabic vocabulary loan is called by al-Attas (2008) as a key term or basic term. Key terms refer to a set of vocabulary contained in the meaning and meaning of the natural view of Islam. For example, the term mentioned above 'Majesty of the Great Gods' has been exchanged with the word 'Allah' which is reasonable following the path found in surah al-Ikhlas.

Actually a subject that involves changing meanings and borrowing from this vocabulary implies a gradual recruitment process. In connection with this, we can say that translating meaning or change in meaning from the original vocabulary into the meaning of Islam occurs first. After that, the loan occurs. This was indirectly observed by a great Patani scholar, Sheikh Ahmad al-Fathani (Mohd Tarmizi, without date). It was in the fatwa group entitled Al-Fatawal al-Fathaniyyah. In question number four, he has established a method for changing some key words from Champa (al-Fathani, 2000). Generally, Sheikh Ahmad explained that what needs to be done first is to sympathize with the existing vocabulary meanings. After that, if it is not suitable, it is borrowed from Arabic or Malay.

In addition to characters and vocabulary, new language phrases also carry the meaning of applying grammar methods. That is, Malay is a new language for applying the grammatical method of Arabic. This application of the nahwu method can be seen in religious works starting from the translation of the work of 'Aqa'id al-Nasafi in 1523 (al-Attas, 1988) so that, perhaps, the beginning of the 20th century. This phenomenon, however, was not only the application of blindfolds but also accompanied by manipulation of the grammar method carried out by some Malay scientists. Among the most important are Raja Ali Haji, Haji Said Sulaiman and Abdullah Abdul Rahman. 
The teleology, sociology and language inheritance described above are the basis for the assumption that Malay is a new language after his conversion. Because Malay has become a new language, this language must be different from the previous Malay language which is said to be regarded as a language laden with values of wisdom and culture besides being not so powerfully looming in a pure spirit and spirit (al-Attas, 1972). Also, not only must the spirit and body of this new language be different, but the name must also be known as another name. Therefore, there is a suggested name, namely Jawi language (Muhammad Syukri, 2017)

\section{Is there a Jawi Language Own Language?}

The existence of the language spoken as Jawi language has long been recognized by adventurers and writers whose names have been mentioned before. Even Malay scholars also use the terms Jawi in their works (Muhammad Syukri 2017: 26-27) which summarizes some parts of ancient scientific work about the use of Javanese. Di Za'ba (2013: 20), for example, states that the Jawi language is not considered a new language that must be distinguished from Malay. Jawi language is only one of various Malay languages even though this language is full of Arabic influences and is only used in writing religious works. Za'ba (2013: 25) dubs this Malay language as a book language.

This is to say that if it is judged in terms of conversion of Malay language linguistics does not give birth to a new Malay language that must be named as Jawi language. The name 'Jawi', which replaces 'Malay', which is used as a ratio to the native owner / speaker of the language, is a practice absorbed from Arabic writing which indeed refers to Malayonesia as Jawi or Javanese land. The adoption of the names of Jawi languages in past religious works is even inconsistent: some use them as Malay and there are Jawi languages. However, according to Muhammad Syukri (2017: 27), "... haqiqat that the term Jawi is used by the 'ulama' itself shows its existence and the use of the term Malay by 'ulama' which later does not deny the existence of this Jawi language."

Thus, the Jawi language is the place of marriage between Arabic and Malay. What's interesting is that this kinship relationship is based on male nasab, namely Arabic = 'father' and Malay = 'mother', so Jawi language is familiar with the word 'father' and is no longer related to the term 'mother'. This means that the birth of this marriage is completely cut off from the 'mother' street language group and must be grouped into 'father' language. In other words, the Jawi language has its own spirit and body which directs its lines directly into Arabic, not Malay.

To assess this response, we first need to look at the reasons, namely:

1. Jawi language is a new language which is defined as "the Malay language of Islam written in Arabic letters in addition to Malay letters which obey the discipline of the book" (Syukri 2017: 30).

2. Jawi is considered a language other than Malay. The reason is that this language is Arabic. His brothers are the language that has been recruited. This is different from Malay because Malay is a Malay / Malay language and its brothers are Malayic language groups.

3. The viscosity of the influence of Arabic has changed the spirit and body of the Malay language into a new language that is more familiar with the source language, namely Arabic (or 'father' language according to the analogy above). This influence, as already mentioned, appears in character, vocabulary, semantics, syntax and pragmatic language. This was stated by Muhammad Syukri (2017: 13) that: "... what is meant for the new ... is a language that even expresses pre-existing 
expressions, but in ma'na terms; default sentence; verse form and rules; style of expression; qa'dah in order; Use the same font as new ... "(original pressure).

4. Continuing propagation into Arabic is not solely based on linguistic teaching but also has religious considerations: that by obeying the flow of the Arabic language, which is the language of the Koran and authoritative language reveals the natural view of Islam, the Jawi language is indirectly bound by one religion or full religious sanction.

Is it true that the Jawi language must be regarded as a new language that is distinctive and different from the Malay language because of the strong influence of Arabic which was implied by Muhammad Syukri's response? Some considerations need to be considered before any pleasure is taken. First, the assumption in language collision theory is a new language of birth as a result of two or more languages that collide in geographical and social space. The existence of Javanese does indeed fulfill this assumption. The reason is that the Jawi language is due to the collapse of the Malay language in Arabic or in other words a clash between ArabIslamic and Malay-Islamic culture. Without such clashes, it is not possible for Javanese to get it. The conclusion is that the Jawi language is a new language originating from clashes.

Second, the question is that language which was born as a result of the conflict of Malay with Malay can really be said as a new language in linguistic meaning and not in the sense of religion? Muhammad Syukri explained linguistic weights, namely character, vocabulary, grammar, pragmatism, and meaning. It turns out that the Jawi language has all the significant linguistic characteristics to allow it to be classified as a new language. However, understanding new languages for the Jawi language if measured by the theory of clash of languages contains little problem. Jawi language is formed not because of face-to-face speech between Arabic speakers and Malay speakers to allow interaction of situations. In other words, the emergence of Javanese is not because of the general atmosphere that occurs in a society whose language is controversial but rather the religious and psychological reasons of the Malays themselves.

Third, related to the description above, the problem here is in terms of usage: is Jawi language used as a whole? Indeed, Jawi language was used very hard in writing Indonesian works before the 20th century. The question is, what is the use other than writing? In other words, are native speakers of the Javanese language, or at least the speakers who use it as a pijin or koine? We cannot answer this question with certainty. Because research on the language used in the speech of Arabs and Malays who received full education in Arabic insofar as this paper was written is still undiscovered - there are only ethnographic and sociological studies of Arabs and Arab peranakans who migrate for example to Indonesia; see the writings of Van den Berg, published in 1886, with the most recent translations in 2010. The question is, do they use language whose structure follows the path of Jawi language or, they only use Malay and / or Arabic?

This raised issue brings us to the fourth consideration, namely if the speaker is native, then why did the old scholars write using Jawi language and standardize the knowledge of the language according to the rules of Arabic language. Muhammad Syukri (2017) answers this question by giving special emphasis on aspects of credibility. In this case, because Arabic is the language of revelation and the official language of Islam and language that has a superior and great scientific tradition, then everything in Arabic must be followed. The reason is that this is none other than the language recruitment movement that will elevate the dignity of linguistic language to Arabic. Thus, the Malay language, in order to elevate its degree to an 
authoritative language, must be guided by the Arabic language whether in carrying out the facts of its natural view to the construction of the rules of nahwu. The guidelines given by Arabic are the ones that eventually bring Jawi language.

This is the reason why the early scholars compiled their work in Jawi language, which was full of Arabic, even though their enthusiasm was still in Malay. If we read the works at a glance, we will find that their sentences are so foreign. The Jawi language does not only appear in religious works, but is also understood by the rules of the nah by Raja Ali Haji in the Language Knowledge Book and the second Bustan al-Katibin is published in a luxury edition by the Employee Foundation. For Raja Ali Haji, as quoted in both of his works and as will be discussed later, the grammar of the Jawi language must be a model of Arabic grammar. This is because Arabic is credible in terms of religion, language and knowledge traditions. The case of Raji Ali Haji is more interesting because he does not only standardize the Jawi language according to the Arabic nahu model, even the Jawi language dictionary is compiled based on the compilation of Arabic dictionary entries.

Perhaps we can agree that the credibility of the Jawi language is said because its interpretation of Arabic lies in the dimension of meaning. The reason is, in this dimension, the fact that an Islamic new view is reflected as stated by al-Attas (1972) and earlier by Herder (Foster 2010). The issue of credibility does not seem to be related to aspects of grammar. The reason is that borrowing grammar from other languages and modeling it into one's own language does not make language credible. The grammatical structure of all languages is complex and simple because this grammatical structure is made to suit the living conditions and the nature of the speakers. Although the question "are better languages than the other" arises (Dixon, 2015), the answer is not as quoted from Humboldt (2000) in his great work which demeaned the structure of other languages and raised the structure of other languages as well as powering down the speakers. The explanation here is that we must not see the tendency of the Jawi language to be Arabic only for religious reasons. The following are some possible hazards that might be taken based on the discussion presented:

First, the realization of a language called Jawi language which is said to be born rather than a combination of Arab-Islamic culture with Malay-Islamic culture is actually only Malay. The word 'Jawi' which is attached to the word 'language', as has become common knowledge, only refers to the writing system. The name of the language and the name of the writing differ, but both remain one language, namely Malay. In this case, the difference between the name of the language and the name of the writing is actually not strange in the world languages. For example, for Japanese, his writings are called Hiragana and Katagana, but the language spoken is generally called the Japanese language. So, the separation of the name of the language and the name of the writing is actually not too strange and there is no need to confuse it.

Second, the Jawi language is not a language that is truly new if it follows the perspective of language convergence. The reason is very simple, that is, Jawi language has no speakers, even this language is not spoken as a daily speaking language. Jawi language, on the contrary, only the language of writing religious and scientific works may begin with translations of Aqaid al-Nasafi (al-Attas, 1988) until the beginning of the 20th century. So, the conditions only used in writing religious works do not attempt to make Jawi language a whole language that requires practice in oral and written writing once. But what about Sanskrit, Ancient Greek and Latin? Don't these languages also have native speakers and are only used in past works? It is true that these languages have no speakers. However, this answer is only 
used for this period. In the past, there were Sanskrit, Ancient Greek and Latin languages, there were speakers, although only in temples like Sanskrit.

Third, because the Jawi language is a language that is only used in writing religious works, then this language must be seen in the framework of diglosia. In linguistics, the concept of diglosia for the first time was introduced by Ferguson (1959). This concept refers to a situation that shows linguistic diversity in a language society. The diversity is not natural in terms of geography such as dialect differences, but the most important thing is diversity and the degree of difference in language usage. Therefore, in the situation of diglosia, a language has high language versus low language, written language versus oral language, standard language versus market language and others. So, the Jawi language is one of the variations in the Malay diglosia sometime in the past, not another language that is truly new.

Fourth, the earlier statement touches on the tendency of the previous scholars to use Jawi in their essays. There, trends such as this are attributed to religious and authority reasons contained in Arabic. However, the slackness shown here tries to see such a tendency to penetrate psycholinguistic binoculars and mastery of second languages. These binoculars are packed into the support set by Herder and the Herderian tradition (Foster 2010, 2011), namely human thinking is bound to language and the cultivation of the fruit of thought and its subjugation is conquered to anything that is expressed power through the language which is the tool of thought. In this case, it is probable that the old scholars thought in Arabic, so the translation of the content of the mind carried out by translating Arabic into Malay indirectly was influenced by the rules of Arabic nahu.

Whatever reason we may present as a counter example to the realization of a typical language that is recognized as Jawi language, but all that is powerless to reject a historical fact: that the Jawi language is a traditional language which contains the body and spirit of the Arabic language and Malay language. In addition, the historical fact also remains: that the formation and development of Malayonesia civilization ago, which began with the Malay Malay Sultanate until the majesty of the Aceh Sultanate and other small Malay kingdoms, Jawi language indeed became a central element.

\section{Jawi Language as a Unified Language of Malayonesia}

A strange thing about Nusantara civilization is addiction to connect awareness as a nation with something more prestigious. The most obvious example of this is linguistic awareness. If we examine the history of Malay, we will realize that in every age the language is known by various names. Kunlun language, so the language was called when the power of Sriwijaya Kedu in the 7th to 10th century. The existence of the Kunlun language which was used as the standard language in all of Srivijaya's power was recorded by the Chinese priest, I Tsing (Yijing). He reported that Kunlun was the language of knowledge because it was used to write works on Buddhism.

Since the rise of Islam, during the reign of the Samudera-Pasai kingdom and the establishment of the Malacca Malay Sultanate and other Malay sultanates, Malay became known as Jawi language. The use of the Jawi language was detected up to Ternate, Tidore, Brunei, Mindanao and others. In this period, a period which might have begun in the 13th century until the beginning of the 20th century with a special focus on 1824 (through the English-Dutch Treaty), Jawi language was united to all Malayones (al-Attas, 1972). In other words, ethnic diversity in Malayonesia is united in the framework of "Malayness" through one main source: Jawi language. 
This historical fact shows that the formation of Malay-Islamic civilization in Malayonesia only gained form through linguistic consolidation by making an official language which served as a communicative tool between the various tribes. Perhaps modern Indonesia also learns from this historical fact with "Soempah Pemoneda": one nation, one race, one language.

\section{Jawi Language as a Diplomatic and Constitutional Language}

In 1521 and 1522, two letters were written by the Sultan of Ternate and Tidore to Kapitan Tetua (Blagden, 1930). Even though it was presented to foreigners, the letter was written in Jawi. These two letters are the oldest Malay letters found today. The existence of both proves that Jawi language is an important diplomatic and linguistic language in state affairs. Maybe this fact doesn't surprise us. The reason was the Sultan of Ternate and Tidore wrote to the Portuguese captain who was a Malaysian in the country. Valentjin and Bowrey, among others, have noted that Jawi language is used throughout Malayia (Collins, 2005). So, the assumption is that all people who settled in Malay at that time could understand Jawi language. We will be more surprised if we look at the Sultan of Aceh who wrote a letter to the queen at the Britannia in Javanese (Gallop, 1994). Our hope is whether the queen understands it? But, no matter, why the queen has an interpreter. Similarly, when the Sultan of Melaka sent a message and sent a message to Emperor Ming in China, it was a translator. To our surprise, the fact is that Jawi is widely used as a diplomatic language.

Another example that can be shown to prove this is the research that the author did with his fellow investigators on letters written by VOC governors to Sultan Sumenep, Madura (Noriah \& Mohd Tarmizi, 2017). Dozens of VOC governor's letters from the Leiden library analyzed the sociolinguistic aspects of 19th-century Malay. It cannot be denied that the letters tried to highlight the aspects they wanted to see. However, another thing that shows the uniqueness of Jawi language as a diplomatic language is that the language is used as a quiet colonial tool.

First, as a diplomatic language. Special research into a letter written by Johannes van den Bosch (1830-1833), Jean Chrétien Baud (1833-1836) and Leonard du Bus de Gisignies (18261830) to Sultan Abdurrahman Pakunataningrat I (1811-1854) highlighting the empowerment of Jawi language as a diplomatic language. In these letters, all matters of administration of the colonial office in Betawi and all the wishes of the Queen in the Netherlands were delivered smoothly with language games that obeyed the rules outlined by the Malay letter writing, for example compiled by Raja Ali Haji (2005).

Second, besides diplomatic language, the Jawi language is also manipulated as a silent colonial tool. This can be seen through the use of nouns and pronouns. In addition to fulfilling aspects of Malay politeness, the use of pronouns and titles as discussed also has an implicit goal, namely colonialism. Colonialism here is defined as an indirect recognition of the sovereignty of colonial power. This implicit recognition is evident in the use of titles to refer to the Dutch king / queen. In this case the Dutch king / queen uses the term 'The Most $X$ ' which in Malay is usually only used as a reference to God. However, three Governors generally use the title 'The Most $X$ ' specifically for the king / queen.

At the same time, pronouns and titles used for senders and recipients only imply subordinate relations or horizontal relations. This is evident in the use of 'us' and the title of 'our best friend'. The use of pronouns and titles indirectly implies the existence of a hierarchy in the Dutch-Dutch colonial world which can be illustrated in the figure below. 


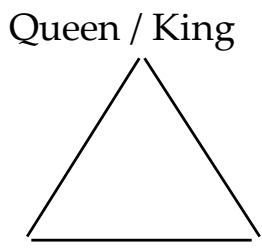

Sender - Recipient

This hierarchy clearly shows that all obedience and respect must be directed to the king / queen above. Therefore, the title used to refer to it must also reflect its height. In this case, it turns out that the beauty of language is not merely manipulation of expressions, sentences and words to fulfill politeness rules or to ensure that "beautiful and beneficial" things are sprung (Braginksy, 1998), but are absolutely empowered to become tools of Dutch colonialism in the Indies in particular and in the Malay world generally by only using certain words.

There is one more thing that needs to be shown here, namely in Jawi, Malayonesia civilization has thoughts about the theory of leadership and stewardship that stands with alMawardi through al-ahkam al-sultaniyyah besides being used to innovate the theory of Nicolo Machiavelli in Il principe. This is what Shaharir (2010) tried to make. Based on the classical and great text of Jawi language, namely Hikayat Raja Pasai, Sulalatus Salatin and Tajus Salatin, Shaharir shows that Malayonesia civilizations have aberrant and pure leadership axioms of leadership and stewardship. The axioms in question can even be used to criticize and enhance the axioms that exist in the theory of modern leadership based on Greek and Western civilizations.

\section{Jawi Language as a Language of Science and Language Communication Science}

The language of the soul of knowledge, thus Shaharir $(2009,2012,2015)$ devotes with the intention to change the expression of the language of the soul of the nation, and also knowledge is the soul of civilization. There are two things that need to be understood in terms of the expression of the language of the art of science. First, the language of science. Second, the language of communication science. Language of science is a language that creates and develops terms that are capable of accommodating scientific concepts that are genuine and transparent. Language communication science is a language that is used as a vehicle for articulating scientific ideas and insights. What's interesting is that the Jawi language is a powerful language that plays a role as the language of science and the language of communication. To prove this statement, let us review one of the branches of science that was successfully created and developed in Jawi language, namely linguistics.

\section{The Birth of the Linguistic Tradition of Malayonesia}

"Until I have compiled this book, it is very rare for people to talk / write about the character of Sheikh Ahmad al-Fathani who contributed to the development of languages on this overseas, whereas if we investigate his services to the language it is very great. His services and efforts are so numerous, but seemingly lost in the view of modern linguistic reviewers."

That is Wan Mohd. Saghir (2005: 151) wrote in his work on Sheikh Ahmad's thoughts. Complaints on Wan Mohd. Saghir above, especially in his last sentence, is not a complaint that is unfounded, instead the encouragement that brings it can be displayed on a clear awareness that appears in his heart about the situation during the science of Malay linguistic history 
which clearly ignored the role and services of Sheikh Ahmad. It turned out that the piercing temptation proved Wan Mohd. Saghir remains connected with the development of linguistics in this country.

The above statement was delivered by Wan Mohd. Saghir in 2005. This is parallel to the publication of his work. However, it is very unfortunate that after many years passed the state of science of Malay linguistic history still did not also reveal significant changes: it turned out that even now its panorama was gloomy, that is still the same as in 2005; as if nothing changed. Evidence that shows no change in the situation can be seen in the graphic work of the Malay linguistic history which is rather new, among others, a work published five years later, namely Nik Safiah (2010). This work is generally still more outrageous to the same literary figures as found in the writings of the 1950s, for example Teeuw (1959).

Molek was also reviewed a little about what this caused. If it is reviewed by any graph writing of the Malay linguistic history, there are always two names which are often referred to as representing the language of the 19th century watan. The two names are Raja Ali Haji and Abdullah bin Abdul Kadir Munshi. However, the first name is often referred to as compared to the second name. This is because he is indeed a master speaker. He also wrote Malay grammar and lexicography. The title is Bustan al-Katibin and the Language Knowledge Book. These two works belong to the great work of Malayonesia civilization (Alam Melayu). This is following the welding made by the publisher responsible for publishing luxury editions both, namely the Employee Foundation (2005). The second name is also always called not because he wrote anything grammar (although he was said to have intended to write it, it was not accomplished), but only because of his concern for the Malay language. The worrying attitude that Munshi Abdullah highlighted was clearly recorded in his autobiographical work, namely the Story of Sailing Abdullah and Hikayat Abdullah.

Apart from Raja Ali Haji and Munshi Abdullah, we no longer hear the names of other watan languages that lived in that century. The graphic works of the Malay linguistic history and works of Malay recitation in general are on the contrary continue to jump to the beginning of the 20th century by offering a discussion about several other figures born on Penyengat Island (its focus is to talk about authorship in general and literature) and in Johor (giving special support to the Karang-Mengarang DiRaja Johor Official), besides, of course, Zainal Abidin Ahmad or Za'ba himself.

What is certain is this situation, namely the missing link in the discussion of graphic works of Malay linguistic history and works of Malay recitation, inviting a subtlety for anyone interested in pursuing the Malay linguistic strain. The subtlety becomes even more so due to several other facts.

First, if traced the historical record, as reported by Shaharir, who plucked Muslims (in Shaharir, 2015), that since the 17th century, in Aceh Dar as-Salam, there has been the establishment of a higher education institution or university (if using the term modern). The university campus is at the Bait al-Rahman Grand Mosque. The University in Aceh Dar asSalam is said to have 17 faculties formed based on the specialization of the field of study. One of the faculties is related to the study of languages called Dar al-Nahwu. With the existence of Dar al-Nahwu, it certainly allows us to suppose that the faculties must be related to the study of languages in the Islamic tradition. Then, of course, Arabic recitation. However, we can also guess that perhaps Malay language is also taught there. Because what underlies this assumption is Andaya's (2008).

According to Andaya (2008: 116-137), the rise of Aceh as a master power (politics and science) in Malayonesia in the 17th century and the 18th abab was due to its association with 
Malay and Malay. We know that Malay language is not negative in Aceh. They have their own native language, which is the language of Aceh, which is different from the Malay language, although closely related to the Malayo-Chamik branch (Blust, 2009: 731). However, in Aceh at that time, the official language of politics and science was Malay. This does not seem surprising because Malay is indeed the main language in Malayonesia. What we want to highlight here is a way that allows speakers not to master the Malay language perfectly to allow articulation of thoughts to flow with light. Of course mastery like this does not happen in 'look-up' and 'hear' because the method of language learning like this results in defective mastery. See all Malay languages used by European adventurers in Malayonesia. The mastery of perfect Malay language as found in the works of great scientists in Aceh is only a reality of learning in an official way. This is what might be taught at Dar al-Nahw as we thought.

Secondly, in a statement from Sheikh Jalaluddin, written by Fakih Saghir (2002), who reported a strong polemic between traditionalist (Old People) and modernist (Youth) people in Minangkabau land in the 18th century, there was an indirect mention of Islamic boarding schools. teaching Arabic grammar books, and maybe also the Malay grammar book? Although the author does not mention the title and name of the authors of the books used as teaching materials, at least we may imagine about the existence of teaching activities of grammar books in the Malay world, just as we thought in Aceh.

Indeed, the edicts of the Aceh Dar as-Salam and from the Minangkabau land that led to Fakih Saghir's letter were not effective evidence that could be used to ensure that there was a firm certainty about the existence of Malay grammar writing and teaching traditions in Malayonesia. Both of them are nothing but mere possibilities that are still not trying to be validated for sure to be true. Such edicts will certainly change their dignity to the dignity of certainty if they encounter works or Malay grammar manuscripts that were allegedly taught at that time.

Indeed, it is not denied that there were Malay grammar works that emerged in the 16th, 17 th and 18th centuries, it was said that in the 17th century the birth of the earliest Malay grammar works by Johannes Roman (Collins, 2005; Karim, 2006). However, it is very unfortunate because the related works, including the earliest known Malay language works, were written and translated by European people in European languages (ie in Dutch, English, Latin and German).

This paper is not interested in the Malay grammar written by the European nation. The interest of this paper is only to the Malay grammar works written by people in Malayonesia itself - watan's language or language. However, Malay grammar works written by local people who have been met as of today date rather than compared to those written by European people. The earliest work found was only in the mid-19th century. The related work was written by the scientist mentioned before, he is Raja Ali Haji. Other works, if any, are still not found. After Raja Ali Haji, Malay grammar works in the early 20th century only appeared in Johor, including Hajj Md. Said Haji Sulaiman in 1937 (translated in 1993) and Abdullah Abdul Rahman in 1912 (converted in 2017).

It seems, as agreed upon by scholars, only Raja Ali Haji as the only language of watan who occupied himself discussing Malay language and grammar in the 19th century. The problem is, does this coincide with the historical fact ?; is it true that Raja Ali Haji is an official? Right or not, it still cannot be ascertained that valid evidence is found. However, luckily the report from Aceh and Fakih Saghir's letter which was stated beforehand in a nutshell envisioned the possibility of the existence of other people who helped pursue Malay language and grammar. 
The problem is, if there is anything other than Raja Ali Haji, who is the subject of the discussion? So far there is no definite answer given by the graphs of Malay linguistic historians and aspirants in the field of Malay studies. Jan van der Putten (2001), for example, once mentioned Haji Ibrahim as a scholar of Malay language who is comparable to Raja Ali Haji. Both of them, namely Haji Ibrahim and Raja Ali Haji, lived contemporaries even closely; both were involved in helping Herman van der Tuuk and Herman von der Wall to prepare DutchMalay dictionaries (Putten, 2001; Putten \& Azhar, 2007). Even though Haji Ibrahim and Raja Ali Haji were built up from the Penyengat Island courtesy tradition, Haji Ibrahim was more thick with marhean nuances in his language recitation compared to Raji Ali Haji who was still attached to the palace language.

However, the figure, namely Haji Ibrahim, although said to be a Malay language scholar, is merely referred to as "... a researcher, an authority on Malay language and culture, an informant for teaching materials in his own right " Thus according to Andaya (2002: 573) in his spotlight on Van der Putten's work on Haji Ibrahim's letters. To be sure, there is the same as Van der Putten or Andaya, the acceptance of Haji Ibrahim as a person who has authority in matters of Malay language without being included with a deep conversation about the language thinking he has failed. This is due to the support of Putten and Andaya is the content of the letters and their impact on the field of Malay recitation in general.

So, perhaps the conclusion is that only Raja Ali Haji is the only language of watan in the 19th century. However, with this affirmation, we are once again overwhelmed by doubts: where might a language that is abab is said to be a lingua franca and a language that is a builder of Malayonesia civilization is so quiet in giving birth to sensitive figures regarding the rules and 'art of creating nahu 'the language? So, there must be figures other than Raja Ali Haji even though this is just a guess. And, if this guess is true, there are also other questions that must be answered, which is why they are fossilized or neglected in the graphical work of Malay linguistic history? So, the time came to refute this matter. The existence of the Jawi language was also participated in a meeting with the birth of the linguistic tradition of Malayonesia. Two linguistic figures who adhere to Malayology linguistic itiqad will be discussed briefly in the next section. The two figures intended were Raja Ali Haji from Riau and 'Abdullah bin Abdul Rahman, mufti of the kingdom of Johor in the 1920s.

\section{Raja Ali Haji}

As mentioned above, Raja Ali Haji compiled two books that laid the principle on what we have considered as the linguistic tradition of Malayonesia. The two books that were intended were the Al-Katibin Bustan and the Language Knowledge Book. The following summarizes the contents of these two books:

a. Bust al-Katibin

1. Bustan al-Katibin is a book that sets the principles and ways of knowing Jawi. in this book, Raja Ali Haji uses Arabic nahu to apply to the narrative of Jawi language. Below is a summary of the Jawi language language category (Mohd Tarmizi, 2014). Isn / Name (KN)

a. Isim Nakirah / KN is uncertain.

- can also be equated with the current $\mathrm{KN}$ that is understood today.

b. Isim Ma'rifah / KN certainly.

i. isn dam / Name pronouns.

ii. Isim al-'alam / special KN.

iii. Isim al-isyarah/ Word of mouth. 
iv. Isim mausul/ Relative noun.

v. Isim idafah/ Backup word.

2. Fi'il/ Verb

i. Fi'il Madi/ word of the past.

ii. Fi'il Lazim/ non-transitive verb.

iii. Fi'il Muta'addi/ transitive verb.

i. No deliberation.

- a single act, only involves the subject.

ii. Deliberation on deeds.

- repetitive actions, may involve others.

iv. Fi'il Mudari/ "temporal" and "later" verbs

v. Fi'il $A m r /$ verbal verb.

vi. Fi'il Naqis/ defective verbs that require predicates.

vii. Fi'il Muqarabah/ the verb aids almost.

viii. Fi'il "praise "and" cela".

ix. Fi'il "suspect "and" sure".

3. Harf/ Particle / Word of Duty

a. Harf which has ma'na and can stand alone and benefits the ma'na and the words.

b. Harf which only benefits the ma'na and the words.

In view of the classification made by Raja Ali Haji, there are only three words in Malay: i) nouns; ii) verbs; and, iii) particles or including job assignments. The question is why only three classes? That, nothing else is related to the source language of its reference, Arabic. The Arabic language, as well as the languages of the other Semitic clan, does have the three words as used by Raja Ali Haji. Perhaps he only took classes from the Arabic language, then looked for his match in Malay. The result, definitely trying to find the match. This can be detected in the above table as the three are universal (Comrie 1981); is in any language. However the question should be continued, whether with the three classes able to classify the true Malay language class?

In addition to the equations of the word classes and their definitions, it can also be tracked by other similarities through the examples of the sentences used by Raja Ali Haji. In the case of example sentences, Arabic, for basic verse, is usually built on KSO structure (verbs - objects). Meaning, verb or deed, followed by subject or perpetrator, furthermore, object. Raja Ali Haji also uses the same structure even though the text structure of the Malay language is not the same as the structured SKO (subject - verb - object). Examples of Malay verses with the KSO structure he used, among others, "correspond with me with qalam" and "have arched Si Zaid". These two examples are clearly constructed based on the KSO structure.

Why is the pilgrimage of Raja Ali Haji? It's a bit difficult to answer this question. However, the answer can be traced back to the Arab-Islamic linguistic tradition that has been discussed earlier. The method of pilgrimage of Raja Ali Haji was thus in al-sama ', which is the method of selecting language information to be used as a back-up for grammatical construction. Because Raja Ali Haji used the classification of words and structure of sentences based on Arabic, it was hypothesized that he did apply al-sama 'in his analysis. However, the application of al-sama 'was not from the Malay language information "as is" in the sense of taking language information as used by the Malays although in his letter to Herman Von der 
Wall it was stated in the same way (Putten \& Azhar, 2007). On the other hand, the language information is a direct translation of the al-sama category 'in Arabic.

Perhaps it is true that Hashim Musa's statement (in the introduction of the 2010 Knowledge Book) implicitly implies that the nature of the grammatical grammar which prioritizes Arabic by Raja Ali Haji is none other than preserving the characteristic grammar of Malay language in Islamic languages. In Islam, the main language is Arabic due to religious channels. So, Raji Ali Haji wants to retain that element. Therefore, if seen in two of his works, Bustan al-Katibin and the Book of Knowledge of the Language, not only the equations have been discussed, but all Malay grammar reconciliation is matched with Arabic grammar. This is where the issue of "what shoes" is; that what is being taught about the grammar of the Malay language by Raja Ali Haji, with its teaching nature, is influenced by the "what's supposed to be" statement for Malay speakers. And, "what is supposed to be" is nothing but to include Arabic elements through the al-sama procedure.

b. Book of Language Knowledge

The Book of Knowledge of Languages contains the efforts of Raja Ali Haji to compile an authentic Jawi language dictionary. With authentic, the meaning of Raja Ali Haji is the correct Jawi language in terms of its meaning and in spite of the effects of the ineffective use (Putten, 2002). Raja Ali Haji uses special rules to achieve this. As the Jawi language grammatical method and methodology compiled in Bustan al-Katibin, the words in the Language Knowledge Book also follow the Arabic language concept, which is the concept of the keyword and, most importantly, is to emphasize the position of the dignity (Hashim, 2010: xii). Therefore, this dictionary in the chapter al-Alif first defines seven key words is Allah, alNabi (Ahmad), al-Ashab, al-Ahbar, al-Insan, al-Awwali (al-Dunia) Hereafter.

Although the dictionary is solved only by alif to cha, but the insight contained in it affects the importance of Arabic to form a special observation of Jawi language. Insights on keywords for example are derived from the Arabic language that is brought into the spirit into the Jawi language. The concept of a keyword, according to al-Attas (2008) is a set of interrelated terms. The linkage allows it to form a whole field of semantic field as well as uninterrupted as a result of language reshaping.

The insights on the keywords are manifested in the practice of Arabic language past amongst the most famous are Kitab al-Ayn by Abu Abdul Rahman al-Farahidi and al-Qamus al-Muhit by Muhammad ibn Ya'qub al-Firuzabadi. In fact, the insights contained in the Bustan al-Katibin and the Book of Language Knowledge clearly show how strong the influence of Arabic in giving a look, face and spirit to the Jawi language which is the language of religion and knowledge of the Malay people.

\section{'Abdullah bin Abdul Rahman}

'Abdullah bin Abdul Rahman was the Yang DiIntertian of the Johor Islamic Religious Department in 1932-1947 and also the Yang DiPertuan Pakatan Melayu Book of Johor (P.Bm.PB Royal) (Muhammad Syukir, 2017: 35). He authored a book titled Kitab Suci Melayu. This book contains a description of the grammatical method of Jawi language which is also based on Arabic language. According to Muhammad Syukri (2017: 30-31), the grammar of Jawi based on the Malay Verses of the Book contains the following categories

1. [Began] Word Beginner 1

a) [So] Word News 1.1

b) [So] News Word 1.2

c) [Then] News Kata 1.3; and so on 
2. [Started / Shahdan] Word Beginner 2

a) [So] Word News 2.1

b) [So] Word News 2.2

c) [So] News Word 2.3 / Word Beginner 2.3

1) [Chronicle] Word News 2.3.a

2) [Then] News of Words 2.3.b

3) [Fa'idah] Word of Wording 2.3.c - additional information

3. [Begins] Words Beginner

Guidance: Word

Beginner $=$ Subject

Word News $=$ Predict

In summary, each sentence in Jawi is formed through the combination of the Word of the Beginners. The formed sentences are separated by the word connectors, or in their modern terms called as discourse markers, such as starting, shahdan, and so forth (Muhammad Syukri, 2017: 30).

If we compare the grammar of the Jawi language compiled by Raja Ali Haji with 'Abdullah bin Abdul Rahman, we will surely find a little difference, namely: first, Raja Ali Haji applies 100\% Arabic grammatical terms while not so for' Abdullah; secondly, the method of Raja Ali Haji's grasp is more focused on single verses, while Abdullah's grasp method is more geared towards complete discourse by linking single verses with discourse markers. Despite having a slight difference, once again we can see how strong the influence of Arabic on Malayalam linguistic traditions.

\section{Conclusion}

Jawi language is a language born through a bump of Malay and Arabic. Jawi language plays an important role in the formation of Malay civilization. This role covers three aspects. First, the Jawi language serves as the language of unity. Secondly, the Jawi language is a diplomatic and state language. The three Jawi languages are the language of science and communication science. Thus, Jawi language has a very important and substantive influence in the formation of Malay civilization. It should not be too much if we say that without the Jawi language, the superiority of Malay civilization in the 13th century to the mid-19th century and the beginning of the 20th century is merely imaginary, impossible to come true. 
"JAWI" LANGUAGE AND ITS ROLE IN ESTABLISHMENT

CIVILIZATION OF MALAYONESIA

Noriah Mohamed

\section{Bibliography}

‘Abdullah Abdul Rahman. 2017. Petuturan Melayu. Kuala Lumpur: Akademi Jawi Malaysia.

Adelaar, K. Alexander \& Prentice, D. J. 1996. Malay: its history, role and spread. Dlm. Atlas of languages of intercultural communication in the Pacific, Asia, and the Americas. Berlin: Mouton De Gruyter.

Andaya, B. W., 2002. Ulasan buku His Word is the Truth: Haji Ibrahim Letters and Other Writings. Journal of Southeast Asia Studies 33(3): 561-594.

Andaya, L. Y., 2010. Leaves of the same tree: trade and ethnicity in the Straits of Melaka. Singapura: National University of Singapore Press.

Ansaldo, Umberto. 2007. Contact languages: ecology and evolution in Asia. Cambridge: Cambridge University Press.

Azhar \& Putten. 2005. Dalam berkekalan persahabatan: Surat Raja Ali Haji kepada Von der Wall. Jakarta: KPG Gramedia.

Azhar Simin. 1993. Sintaksis wacana yang. Kuala Lumpur: Dewan Bahasa dan Pustaka.

Blagden, C. O. 1930. Two Malay letters from Ternate in the Moluccas, written in 1521 and 1522. Bulletin of the School of Oriental Studies, 6(1): 87-101.

Blust, R. 2009. The Austronesian languages. Canberra: Pacific Linguistics.

Braginsky, V. 1998. Yang indah, berfaedah, dan kamal: sejarah sastra Melayu dalam abad 7-19. Jakarta: Indonesian-Netherlands Cooperation in Islamic Studies

Collins, J. T. 2005. Bahasa Melayu bahasa dunia. Jakarta: Penerbit Obor.

Comrie, B. 1981. Language universals and linguistic typology: Syntax and morphology. Chicago: University of Chicago Press.

Dixon, R. M. W. 2016. Are some languages better than others? Oxford: Oxford University Press.

Fakih Saghir, 2002. Surat keterangan Syeikh Jalaluddin. Peny. E. Ulrich Kratz dan Adriyetti Amir. Kuala Lumpur: Dewan Bahasa dan Pustaka.

Ferguson, Charles. 1959. Diglosia. Word 15(2): 325-340.

Foster, Micheal N. 2010. After Herder: Philosophy of language in German tradition. Oxford: Oxford University Press.

Foster, Micheal N. 2011. German philosophy of language: From Schlegel to Hegel and beyond. Oxford: Oxford University Press.

Gallop, A. T. 1994. The legacy of the Malay letter: warisan warkah Melayu. London: The British Library Publishing Division dan Perpustakaan Negara Malaysia.

Hidayatullah, Moch. Syarif. 2012. Bustân Al-Kâtibîn: Kitab Tata Bahasa Melayu Pertama Karya Anak Negeri, Thaqâfiyyât, Vol. 13, No. 1, (Yogyakarta: Fakultas Adab dan Budaya UIN Sunan Kalijaga.

Hashim Musa. 2010. Pengenalan kepada Kitab Pengetahuan Bahasa. Kuala Lumpur: Yayasan Karyawan.

Humboldt, Wihelm von. 2000. 'On Language': On the diversity of human language construction and its influence on the mental development of the human species. Cambridge: Cambridge University Press.

Karim Harun. 2006. Sejarah linguistik: Nahu bahasa Melayu abad ke-17. Tidak diterbitkan. Tesis Ph.D Institut Alam dan Tamadun Melayu, UKM.

Mahadi Tengku Sepora Tengku dan Sepideh Moghaddas, 2012. Language and Culture, International Journal of Humanities and Social Science, Vol. 2 No. September.

Md. Said Haji Sulaiman. 1993. Jalan basa Melayu. Kuala Lumpur: Dewan Bahasa dan Pustaka. Mohd Tarmizi Hasrah. 2014. Adakah nahu beracuan sendiri? Kesturi 24 (2): 66-91. 
Mohd Tarmizi Hasrah. Sheikh Ahmad al-Fathani dan tanda bahasa. Naskah.

Muhammad Syukri Rosli. 2017. Petuturan Melayu: memahami kunci bahasa Jawi. Pengenalan kepada Kitab Petuturan Melayu. Kajang: Akademi Jawi Malaysia.

Nik Safiah Karim, 2010. Panorama Bahasa Melayu sepanjang zaman. Kuala Lumpur: Penerbit Universiti Malaya.

Noriah Mohamed. 1999. Sejarah sosiolinguistik bahasa Melayu lam. Pulau Pinang: Penerbit Universiti Sains Malaysia.

Noriah Mohamed dan Mohd Tarmizi. 2017. Keindahan bahasa Melayu dalam warkah Melayu abad ke-19. Makalah yang akan dibentangkan dalam seminar ASBAM.

Raja Ali Haji. 2010a. Bustan al-katibin. Kuala Lumpur: Yayasan Karyawan.

Raja Ali Haji. 2010b. Kitab pengetahuan bahasa. Kuala Lumpur: Yayasan Karyawan.

Reid, Anthony. 1988. Southeast Asia in the age of commerce. Dua jilid. Yale: Yale University Press.

Shaharir Mohamad Zain. 2009. Bahasa jiwa ilmu: Kes teori kenisbian dalam fizik teori. SARI: Jurnal Alam dan Tamadun Melayu, 27: 143-165.

Shaharir Mohammad Zain. 2010. Pembinaan semula teori kepemimpinan dan kepengurusan Rumpun Melayu. Kuala Terengganu: Universiti Malaysia Terengganu.

Shaharir Mohammad. Zain. 2012. Bahasa penemu ilmu. Makalah undangan di Seminar MABBIM di Brunei, 4 April 2012.

Shaharir Mohammad Zain (pnyt.). 2015. Unsur etnosains di Malayonesia dalam bahasa Melayu sejak abad ke-5 masihi. Kuala Lumpur: Dewan Bahasa dan Pustaka.

Sheikh Ahmad al-Fathani, 2000. Al-Fatawal al-Fathaniyah. 2 Jil. Alih aksara oleh Wan Mohd Saghir berserta teks jawi. Kuala Lumpur: Khazanah Fathaniyah.

Sheikh Ahmad al-Fathani, 1998. Hadiqatul Azhar war Rayahin. Alih aksara oleh Wan Mohd Saghir berserta teks jawi. Kuala Lumpur: Khazanah Fathaniyah.

Syed Muhammad Naquib al-Attas. 1972. Islam dalam sejarah dan kebudayaan Melayu. Bangi: Penerbit Universiti Kebangsaan Malaysia.

Syed Muhammad Naquib al-Attas. 1988. The oldest known of the Malay manuscript. Kuala Lumpur: Penerbit Unversity Press.

Syed Muhammad Naquib al-Attas. 2008. Pengenalan ringkas peri ilmu dan pandangan alam. Pulau Pinang: Penerbit Universiti Sains Malaysia.

Syed Zainal Ariff Syed Jamaluddin \& Noriah Mohamed. 2016. Sejarah perkembangan imbuhan dalam bahasa Melayu. Selangor: PTS Akademia.

Teeuw, A. 1959. The history of the Malay language: a preliminary survey. Bijdragen tot de Taal, Land-en Volkenkunde, 115(2): 138-156.

Teeuw, A. 1961. A crtitical survey of studies on Malay and bahasa Indonesia. The Heague: Martinus Nijhorf.

Thomason, Sarah. 2001. Contact language: An introduction. Edinburgh: Edinburgh University Press.

Van den Berg, L.W. C. (1886/2010). Orang Arab di Nusantara. Jakarta: Komunitas Bambu.

Van der Putten, Jan, 2001. His word is the truth: Haji Ibrahim letters and other writings. Leiden: Research School of Asian, African and Amerindian Studies.

Van der Putten, Jan. 2002. On sex, drugs and good manners: Raja Ali Haji as lexicographer. Journal of Southeast Asian Studies, 33(3): 415-430.

Wan Mohd. Saghir, 2005. Syeikh Ahmad al-Fathani: pemikir agung Melayu dan Islam. Dua Jilid. Kuala Lumpur: Khazanah Fathaniyah.

Wahab Muhbib Abdul, "Peran Bahasa Arab dalam Pengembangan Ilmu dan Peradaban Islam," Arabiyat: Pendidikan Bahasa Arab dan Kebahasaan, Vol 1, No. 1, (Jakarta: 
“JAWI" LANGUAGE AND ITS ROLE IN ESTABLISHMENT

CIVILIZATION OF MALAYONESIA

Noriah Mohamed

Fakultas Ilmu Taribiyah dan Keguruan UIN Syarif Hidayatullah Jakarta, Juni 2014) h. 17

Zainal Abidin Ahmad (Za'ba). 2013. Bahasa Melayu: Kelebihan dan kekurannya. Kuala Lumpur: Klasika Media. 